\title{
A new threat for the globally Endangered Hooded Grebe Podiceps gallardoi: the American mink Neovison vison.
}

\author{
IGNACIO ROESLER, SANTIAGO IMBERTI, HERNÁN CASAÑAS and \\ NOELIA VOLPE
}

\begin{abstract}
Summary
The Hooded Grebe Podiceps gallardoi has been uplisted to globally 'Endangered' recently mainly because of the rapid population decline suffered within the last 20 years due to factors such as nest depredation by Kelp Gull Larus dominicanus as well as destruction of colonies by wind and lake desiccation. During a census of Hooded Grebes during the 2010/2011 breeding season we found a new predator that has not previously been mentioned, the American mink Neovison vison. One individual mink killed 33 Hooded Grebes and consequently destroyed one of the five colonies found in that breeding season. Due to the characteristics of the waterbird assemblage in the area, the impact of mink could be catastrophic.
\end{abstract}

\section{Resumen}

El Macá Tobiano Podiceps gallardoi ha sido recientemente elevado a la categoría de globalmente 'Amenazado' debido a la rápida disminución poblacional sufrida en los últimos 20 años. Distintos factores fueron mencionados como posibles causas, como la depredación de nidos por la Gaviota Cocinera Larus dominicanus, destrucción de colonias por el viento, desecación de lagos y lagunas, etc. Durante la realización de censos en toda el área de distribución del Maca Tobiano en la temporada 2010/11 hallamos un nuevo depredador que nunca había sido mencionado como una posible amenaza, el Visón Americano Neovison vison. Solo un individuo de visón mató 33 adultos de Macá Tobiano y consecuentemente eliminó una de las cinco colonias halladas durante toda la temporada. Dadas las características de las comunidades de aves acuáticas de la zona el impacto de los visones puede llegar a producir una situación catastrófica.

\section{Introduction}

The Hooded Grebe Podiceps gallardoi was discovered in 1974 in the extreme south-west of Argentinean Patagonia, at Los Escarchados Lake, on Las Vizcachas plateau. Shortly after the first description, it was found in a number of nearby shallow lakes on the same plateau, but there were no more than 140-150 individuals (Beltrán et al. 1992). Therefore it was considered rare (Beltrán et al. 1992), and globally threatened in 1988 (BirdLife International 2011). During the late 1970s and 1980s, other plateaus were explored, leading to a revised global population estimate of 3,0005,00o individuals (O'Donnell and Fjeldså 1997). Due to the relatively high numbers and supposedly little habitat disturbance it was downgraded to Near Threatened/Lower Risk from 1994 until 2008 (BirdLife International 2011). Although there are four records from southern Chile, but only one with hard evidence (Barros 2010), the regular breeding and wintering range lies within southern Argentina, in Santa Cruz province, thus it is considered to be an endemic breeder of Argentina. 
After a period without comprehensive monitoring, Imberti et al. (2004) began to conduct searches in the wintering habitat along the Atlantic coast of Santa Cruz province. They found that numbers were considerably smaller than previously thought, suggesting a strong decline. Following this latest evidence, new monitoring was conducted during the breeding seasons of 2009 and 2010 at lakes on the pre-Andean plateaus. After these censuses, the population was estimated to be about 900-1,100 individuals (Roesler et al. in prep.). In light of this new evidence, the species was upgraded to 'Endangered' in 2009 (BirdLife International 2011), although in Argentina it is already considered Critically Endangered (AA/AOP and SAyDS 2008).

During the short history of the Hooded Grebe, many different threats have been mentioned: introduced fish - mainly Rainbow Trout Oncorhynchus mykiss - (but see Lancelotti et al. 2010), nest destruction by the Kelp Gull Larus dominicanus, colmatation of lakes due to desertification caused by overgrazing, volcanic activity, global climate change and fishing by-catch in wintering habitats. The American mink Neovison vison has not been mentioned as a possible threat to this grebe. Fasola (2009) considered it possible, but only because this author considered that all waterbirds within mink range could eventually become potential prey. The American mink has been described as the main threat to grebe eggs and nesting adults, even for North American grebes (e.g. Cullen et al. 1999), which inhabit areas where the mink is native. In the case of the Black-necked Grebe Podiceps nigricollis surplus killing (i.e. killing of more individuals than the predator could eat) by American mink was reported, involving 50 adults in a colony of more than 150 pairs (Breault and Cheng 1988). The authors considered this surplus killing event as 'casual and uncommon'.

The surplus killing of a colony of waterbirds could become frequent when mink meet a naïve prey. Most likely, South American species have few or no defensive strategies against aquatic mammalian predators compared to North American species. Some species sympatric with mink, such as the North American populations of Red-necked Grebe Podiceps grisegina, have probably developed the anti-predator behaviour in which parents neglect the eggs during the night to avoid nocturnal attacks (Nuechterlein and Buitron 2002). Notably, it has been reported that the Great Grebe Podiceps major disappeared from many Patagonian lakes after mink arrived (Peris et al. 2009), although the authors do not mention a cause that could explain that disappearance. Schüttler et al. (2009) found that Patagonian waterbirds that reproduce on the ground with solitary and concealed nests are more likely to suffer nest destruction than those that nest in colonies. In any case, those authors only analyse ground-nesting waterbirds and the situation could be different considering the breeding habits of the Hooded Grebe.

The American mink was first brought to Patagonia during the first half of the $2 \mathrm{O}^{\text {th }}$ century by the fur industry, with the first farms located in Punta Arenas, southern Chile. Shortly after, during the 1940s and 1950s, several breeding farms were opened in Argentina in Chubut and Tierra del Fuego provinces, and eventually several other farms were opened in different parts of northern Patagonia. During the 1960s, the first feral populations were observed in western Chubut province (Fasola 2009). Nowadays there are two apparently isolated populations of American mink in Patagonia, one that extends from northern Neuquén to the extreme north of Santa Cruz, and another in Tierra del Fuego and nearby areas of Chile (Fasola 2009, Fasola et al. 2009; Figure 1a). The population of northern Santa Cruz was already present at least in the early 1980 s (A. Johnson in A. Serret pers. comm. 2011), but several individuals were recently observed in the central part of this province (S. Sturzenbaun in litt. 2011, D. Punta Fernández pers. comm. 2011), suggesting that the two Patagonian mink populations might no longer be isolated.

\section{Study Area and Methods}

Santa Cruz province is located at the southern end of continental South America, between the southern Atlantic Ocean and the southern Andes in Argentinean Patagonia. Forming a narrow belt along the Andes, Nothophagus forest dominates, but the rest of the province is covered mainly by desert-like habitats. Parallel to the Andes and to the east there are several highland basalt plateaus that rise from 500 to $1,500 \mathrm{~m}$ asl. Most of those plateaus hold volcanic and non-volcanic lakes, the 

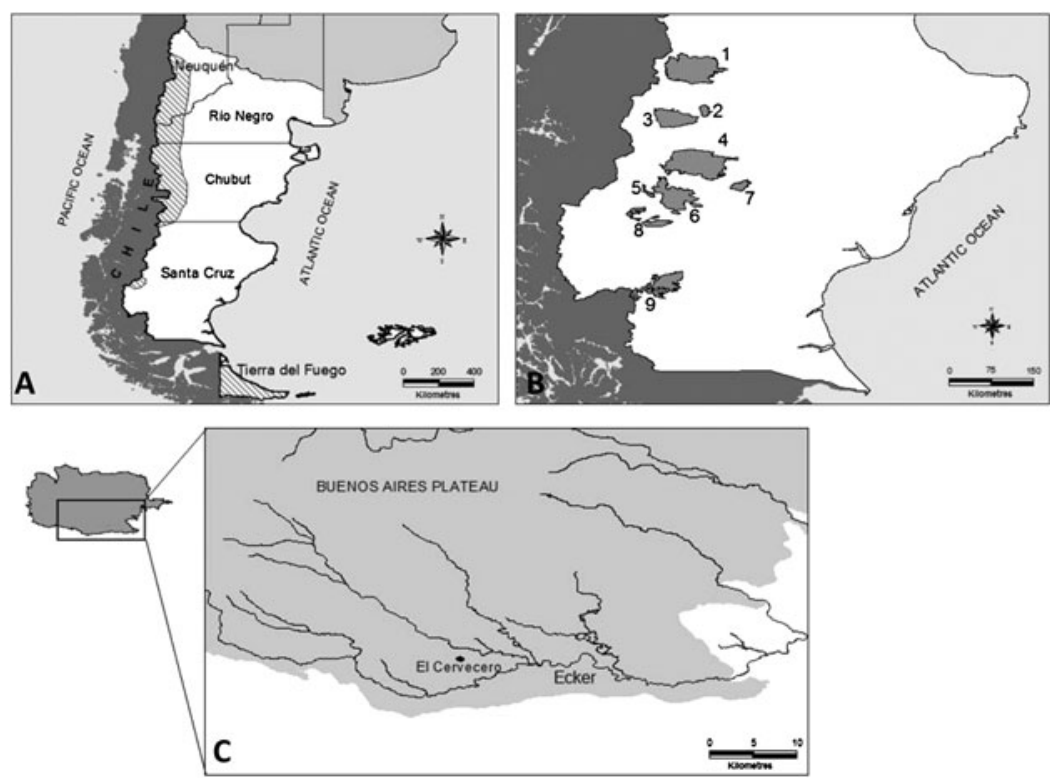

Figure 1. A) Map showing Argentinean Patagonia and the distribution of the American mink Neovison vison (Canevari and Vaccaro 2007). B) Detailed view of the highland plateaus of Santa Cruz province: I) Buenos Aires; 2) Asador Norte; 3) Asador Sur; 4) Strobel; 5) El Moro; 6) Siberia; 7) Cerro Ventana; 8) Viedma; and 9) Las Vizcachas. C) Area of the upper (grey) and lower (white) part of the "9 de Julio" ranch, in the southern part of Buenos Aires plateau, with the tributaries of the Ecker River and "El Cervecero" Lake.

number varying greatly among plateaus. Many of those lakes are crystal-clear and have an aquatic plant, water-milfoil Myriophillum elatinoides, which is important for most aquatic organisms of the area.

From December 2010 to March 2011 we revisited the area that had been monitored during the 1980s, 2008/2009 and 2009/2010, but focused especially on those plateaus that historically held higher numbers of Hooded Grebes: Buenos Aires, Asador Norte and Sur, Strobel (del Viento), El Moro, Siberia, Cerro Ventana, Viedma (Tobiano or Basáltica) and Las Vizcachas (Figure $1 b$ ). The Buenos Aires plateau is crossed by several tributaries of the Ecker River, one of the main tributaries of the Pinturas River, in its south-central part. These rivers are within the Deseado River basin, which drains to the Atlantic Ocean in northern Santa Cruz. Here we visited the ranch "9 de Julio" ( $\left.47^{\circ} 14^{\prime} 28^{\prime \prime} S, 71^{\circ} 11^{\prime} 30^{\prime \prime W}\right)$, in mid-February and early March. In the higher parts of the ranch (c.1,500 $\mathrm{m}$ asl) there are close to 30 lakes, many of them linked to each other by small streams, but some isolated or connected only during early spring. Although we found five lakes that seemed to provide suitable habitat for the Hooded Grebe, only two held grebes, one with 55 individuals and the other with only one. The lake with 55 individuals, named El Cervecero, has 9 ha of crystal-clear water, c.10\% cover of water-milfoil, and a perimeter surrounded by a 10 $\mathrm{m}$ high cliff, typical of these volcanic lakes (Figure Ic).

\section{Results and Discussion}

During the austral summer of 2010/2011 five breeding colonies were found. Four of those colonies were on the Buenos Aires plateau, and one at El Cervecero Lake. This colony included Hooded and Silvery grebes Podiceps occipitalis. Five Hooded and one Silvery Grebe nests were finished and 
contained eggs, and at least two other Hooded Grebe nests were under construction when the colony was visited on 16 February 2011. During that visit we counted 55 Hooded and five Silvery Grebes. On 6 March 2011 we revisited the colony and counted 21 finished Hooded Grebe nests but no trace of the Silvery Grebes. We found 31 dead Hooded Grebes on or near their nests, and two others were found dead on the lake shore, while another 11 individuals were still alive but not in the area in which the colony was located. All the dead Hooded Grebes had the back of the skull destroyed, indicating an attack by a predator, but only one out of the 33 had been eaten. One of the two individuals found outside the colony was hidden inside a hole in the rocks of the lake shore, certainly moved there by the predator. The other individual was on the shore but still in the water and was probably carried there by the strong winds that are usual in the area. These two individuals were the only ones found far from the colony. Most nests held two eggs and some none, probably because they were thrown out when the bird was killed, and no egg shells were found. No Silvery Grebes were found dead and the same five individuals were probably still alive nearby.

Next to the small cave where the grebe was found, we detected an individual American mink. Two hours later we saw what we think was the same individual swimming in the lake. Later, a third observation was made in a different part of the lake, but it was probably the same mink again, as it was close to the area where the mink in the second observation was heading. The injuries observed on all individuals are consistent with the predatory behaviour of the American mink (Breault and Cheng 1988). The supposition that it was only one individual is supported by the fact that the American mink is territorial and the size of this lake is relatively small.

Assuming that the estimated population of the Hooded Grebe is close to 1,00o individuals, a death of 33 represents about $3 \%$ of the total. More significantly, it is important to note that those individuals were part of one of the only five colonies found during a complete breeding season. All 42 eggs found in the colony that were c.15 days old were lost and not a single one hatched. Supposedly, the annual breeding success per pair is close to $20 \%$ (O'Donnell and Fjeldså 1997). Such a survival rate in this mixed colony would have represented a recruitment of c.I\% of the estimated population.

The fact that the American Mink is spreading up into the highlands adds a new and important threat to this already severely threatened species. We should also consider that the only known predators of Hooded Grebe adults in their summer habitats are birds of prey, such as the Peregrine Falcon Falco peregrinus (Beltrán et al. 1992). This fact and the scarcity of native mammalian predators support the idea of naïve behaviour and the lack of an anti-mammalian predator strategy, thus making Hooded Grebe a more likely species for an event of surplus killing by American mink. In view of the discovery of this predator and the other threats that are possibly affecting the Hooded Grebe population, it may be wise to review the current situation and consider a possible revision of its IUCN Red List status.

The highland plateaus of Santa Cruz province hold large concentrations of many different species, such as the 'Near Threatened' Chilean Flamingo Phoenicopterus chilensis, and some areas may fulfill the criteria needed to be considered as a Ramsar site. Many of the historically most important lakes, which held significant numbers of waterbirds of several species including the Hooded Grebe, have already disappeared or are not suitable for waterbirds. This is due to various causes including the introduction of Rainbow Trout (El Islote Lake, Strobel plateau) and drought (Los Escarchados Lake, Las Vizcachas plateau). No more than $25 \mathrm{~km}$ away from El Cervecero Lake is El Sello Lake, which is the most important site for the Hooded Grebe, and holds populations of $>_{10,000}$ individual waterfowl, many of which breed there. The arrival of American mink would have catastrophic consequences on the bird populations of that lake as was proved by Peris et al. (2009), even more so if we consider that most of the species are solitary ground nesters.

\section{Acknowledgements}

We whish to thank to Silvina Sturzenbaum, Adriana Troncoso, Adrían Di Giacomo, Alejandro Serret, Emilio A. Jordan and Diego Punta Fernández for information and comments provided. We 
would also like to thank the people from Estancia 9 de Julio who let us work within their properties. This project could not have been carried out without the financial assistance of Aves Argentinas/AOP, CREO, Canadian Wildlife Service, and Servicios Públicos Sociedad del Estado de la Provincia de Santa Cruz.

\section{References}

AA/AOP and SAyDS (2008) Categorización de las aves de la Argentina según su estado de conservación. Buenos Aires, Argentina: Informe de Aves Argentinas/AOP and Secretaría de Ambiente y Desarrollo Sustentable.

Barros, R. (2010) Algunas evidencias inéditas de aves raras en Chile. Chiricoca 11: 1125.

Beltrán, J., Bertonatti, C., Johnson, A. and Serret, A. (1992) Actualizaciones sobre la distribución, biología y estado de conservación del Macá Tobiano. Hornero 13: 193199.

BirdLife International (2011) Species factsheet: Podiceps gallardoi. Cambridge, UK: Birdlife International. http://www.birdlife. org on (accessed on oI June 2011).

Breault, A. M. and Cheng, K. M. (1988) Surplus killing of Eared Grebes, Podiceps nigricollis, by mink, Mustela vison, in central British Columbia. Can. Field Nat. 102: 738-739.

Cullen, S. A., Jehl, J. R. Jr. and Nuechterlein, G. L. (1999) Eared Grebe (Podiceps nigricollis). In: A. Poole, ed. The birds of North America online. Ithaca, USA: Cornell Lab of Ornithology. http://bna.birds.cornell. $\mathrm{edu} / \mathrm{bna} /$ species/433 (accessed on I June 2011).

Fasola, L. (2009) Distribución, alimentación e interacciones de dos mustélidos semiacuáticos en los bosques andino patagónicos: el Huillín (Lontra provocax), nativo, y el Visón Americano (Mustela vison), introducido. Tesis doctoral. Buenos Aires, Argentina: Universidad de Buenos Aires.
Fasola, L., Chehébar, C., MacDonald, D. W., Porro, G. and Cassini, M. H. (2009) Do alien North American mink compete for resources with native South American river otter in Argentinean Patagonia? J. Zool. 277: 187-195.

Imberti, S., Sturzenbaum, S. and McNamara, M. (2004) Actualización de la distribución invernal de Macá Tobiano Podiceps gallardoi y notas sobre su problemática de conservación. Hornero 19: 83-89.

Lancelotti, J. L., Posic, L. M., Yorio, P. M., Diéguez, M. C. and Pascual, M. A. (2010) Precautionary rules for exotic trout aquaculture in fishless shallow lakes of Patagonia: minimizing impacts on the threatened Hooded Grebe (Podiceps gallardoi). Aquat. Conserv: Mar. Freshw. Ecosyst. 20: 1-8.

Nuechterlein, G. L. and Buitron, D. P. (2002) Nocturnal egg neglect and prolonged incubation in the red-necked grebe. Waterbirds 25: 485-91.

O'Donnell, C. and Fjeldså, J. (1997) Grebes: status survey and conservation action plan. Cambridge, U.K: IUCN/SSC Grebe Specialist Group.

Peris, S. J., Sanguinetti, J. and Pescador, M. (2009) Have Patagonian waterfowl been affected by the introduction of the American Mink Mustela vison? Oryx 43: 648-654.

Schüttler, E., Klenke, R., McGehee, S., Rozzi, R. and Jax, K. (2009) Vulnerability of ground-nesting waterbirds to predation by invasive American mink in the Cape Horn Biosphere Reserve, Chile. Biol. Conserv. 142: 1450-1460.

\section{IGNACIO ROESLER*}

Departamento de Ecología, Genética y Evolución, Facultad de Ciencias Exactas y Naturales, Universidad de Buenos Aires, Pabellón II Ciudad Universitaria (C1428EGA), Buenos Aires, Argentina. 
SANTIAGO IMBERTI

Ambiente Sur. Rivadavia 780, Río Gallegos (940o), Santa Cruz, Argentina.

HERNÁN CASAÑAS, NOELIA VOLPE

Aves Argentinas/Asociación Ornitológica del Plata, Matheu 1246/8 (C1249 AAB), Buenos Aires, Argentina.

*Author for correspondence; e-mail: kiniroesler@gmail.com

Received 25 August 2011; revision accepted 25 December 2011; Published online 9 March 2012 